\title{
The opening of Costco in Iceland: Unexpected meanings of globalized phenomenon
}

\author{
Kristín Loftsdóttir Professor, University of Iceland \\ Már Wolfgang Mixa Assistant Professor, Reykjavík University
}

\begin{abstract}
The multinational retailer, Costco, opened its first store in Iceland during spring 2017. Not only was the opening greatly anticipated but following the store opening, Costco became one of the key issues in the Icelandic media. Our analysis focuses on Costco's opening from insights derived from theories of globalization of mobility, where we emphasize that discussions about Costco in Iceland cannot be separated from the post-crash atmosphere after the massive economic crash in 2008. Our perspective is particularly influenced by Tsing's (2005) emphasis on the unpredictability of global phenomena that move around and transplant in a new context. Our analysis both contextualize Costco's arrival within Iceland's historical and social context and analyzes some of the main themes in the Icelandic media discussion during the opening. The dualistic opposition of 'us' (Icelanders) against 'them' (foreigners), which has been quite salient in Iceland, were largely invisible in discussions about Costco's opening. Costco in Iceland was quickly incorporated into a discourse as a positive force against Icelandic corruption that started after the crash. The 'us against them' themes thus turned from being 'Icelanders against foreigners' into 'the Icelandic population against Iceland's elite retail sector.
\end{abstract}

Keywords: Costco; Iceland; globalization; post-crash. 


\section{Introduction}

It is the end of the summer and we, the authors, are at the library. Már mistakenly hands the woman at the library desk his university identification instead of his library card and when she points out his mistake, he apologizes. She says; "Oh, it is no problem," adding slightly annoyed, "at least you are not handing me your Costco card. It is irritating but everyone these days just hand out their Costco card!" A few months before this incident, on May 23 2017, the multinational retailer Costco opened a megastore in Iceland. Iceland, inhabited by approximately 340 thousand people (Statistics Iceland n.d.-a) with approximately 1.9 million tourists visiting Iceland in 2016 (Icelandic Tourist Board 2017), was described by Steve Pappas, Costco's CEO in England, as a Nordic test market for Costco (Albertsdóttir 2017a). Great anticipation surrounded the opening. For those not able to be present, local newspapers quickly posted images from inside the store, both in printed form and via specialized live broadcasts. These images often had closeups of price tags, as demonstrated in one article simply titled, "See the photos from Costco"1 (Morgunblaðið 2017a). A Facebook group was even created by an individual unrelated to the store, where people shared stories of the prices of different products in Costco (Eyjan 2017a).

Our discussion looks at Costco's opening from theories of globalization and mobility and identifies main themes in discussions in Iceland about Costco's opening in spring 2017. We claim that these themes reflect how the opening of Costco in Iceland became embedded in ongoing negotiations of the meaning of the economic crash in Iceland in 2008, which constituted an important rupture in Iceland's social and cultural fabric. As stressed by scholars within the humanities and social sciences, the figure of the "foreigner" has historically been extremely salient in Iceland, and then generally seen as threatening to the coherence of the nation (Einarsson 2006; Hálfdánarson 2009). As our analysis shows, the foreign ownership of Costco received, however, minimal attention in Iceland when the megastore was opened. We suggest that the economic crash and its aftermath shaped how Costco's arrival was viewed in Iceland, with the historical figure of the dangerous "foreigner" overshadowed by the on-going discussion on corruption and nepotism in Iceland, which in relation to Costco took the form of a strong focus on Costco's potential in lowering prices to regular consumers. During the mid-1990s various neoliberal changes and international agreements and developments, such as the removal of restrictions on capital flow, changed the economy considerably (Ólafsson 2011 , 4). Historically, Iceland's economy had been restricted with capital controls (Ásgeirsson 2008) and strong oligopolies on business (Institute of Economic Studies of University of Iceland 1999).

By positioning our paper within theories of mobility and globalization, we draw attention to the shifting meanings of phenomenon that are seen as global in some sense and their negotiated meanings. Earlier theories of globalization assumed homogenization, where materials and cultural landscapes would become standardized by a hegemonic western or American lifestyle, but this has been seen as too simplistic (Inda \& Rosaldo 2008). Many scholars have, furthermore, questioned, in this regard, how 
globalization is seen as enacted on passive subjects (Inda \& Rosaldo 2008), where some consequently emphasize "hybridization" to draw attention to people locally adapting and often manipulating global forces, for example where fast food restaurants have not necessarily replaced local consumption habits but rather hybridized them (Bordi 2006, 98). Multinational companies also often adapt their products in various ways to local traditions, where they adapt standardized marketing to particular regional or national markets, using different forms of 'strategic regionalism' (Wilken \& Sinclair 2011). Simultaneously, these concepts "local" and "global" should not be reified, with the concept of local, for example, not representing homogenous or bound cultural units but more fruitfully seen as revolving around "contested fields of social signification and interconnection, flows of people, ideas, images and goods" (Moore 2004, 78). Travelling artifacts moving through global landscapes, regardless of their original function and form, become mobilized and materialize in particular ways (Della Dora 2009; Mavhunga, Cuvelier \& Pype 2016). Without dismissing Iceland's interconnectedness with the wider world in the past (Agnarsdóttir 2008), Costco, as a travelling object, can be seen as one more addition to intensified mobility in terms of ideas, people and cultural artifacts that have characterized Iceland in multiple ways (Loftsdóttir \& Skaptadóttir 2016; Lund \& Jóhannesson 2014; Lund, Kjartansdóttir \& Loftsdóttir 2017). To gain a deeper insight of the discussions of Costco's arrival in Iceland, we base our analysis in particular on theories that have emphasized globalization's contradictory effects (see for example West \& Sanders 2003; Tsing 2005). We find Anna Tsing's (2005) use of the metaphor "friction" here particularly useful. Tsing maintains that particular histories and structures, found both locally and globally, create what she calls a "creative friction." Her use of the concept "friction" seeks to capture the diverse interactions and interconnections that constitute part of what we talk about as global and local, where mobility constitutes a part in reconfiguring the concepts themselves. The metaphor of friction, however, also draws attention to the fact that outcomes of the globalization process is not always what is anticipated by those organizing or imaging large-scale projects (p. 3-4). We use the concept of friction here to conclude that the opening of Costco, as one feature of the mobility of economic and "cultural" institutions, reflects a particular reworking of the meaning of the company within Iceland's social and cultural contexts as shaped by continuous involvement with the outside world. Costco, which at first glance could for some present a part of what has been seen as a homogenous part of globalization - a multinational standardized company directed from the global super-power the USA - became incorporated into a post-crash discourse about Icelandic corruption, as an important means to counter Icelandic business elites.

We base our research primarily on analysis of Costco's social and historical environment and on media discussion about Costco in the days before the opening and a month after. A total of 348 articles were collected from various mediums, in addition to monitoring blog discussions about the opening and foreign media discussion. The collection of data started on May 22 and took place until the end of June 2017. The analysis is also based on participant observations in Costco on several occasions, both during the open- 
ing and afterwards. In addition, as both authors live in Icelandic society, we have unavoidably observed in our daily life discussions about Costco's arrival to Iceland, which has been a major topical issue in workplaces and gatherings of friends and families, in addition to other public spaces where communication takes place. Furthermore, we took informal interviews in the store itself. Our conceptual framework emphasizes not only what is said or written, but also the silences and blank spaces in the discussions (Kutsche $1998,10)$. We see such an approach as an important part of the contextualization of data within the larger social and cultural fabric and these silences are often as equally important for analysis as what is said or done.

We start the discussion by giving a broad outline of the Icelandic economy, where we give a sense of Iceland's historic business environment and effects due to the 2008 economic crash. The second section provides an overview of Costco as an American but increasingly international company, as well as an ethnographic description of Costco's opening in Iceland to give a deeper context of the media discussions. Finally, we draw together the main themes that characterized the media discussion when Costco opened. Our analysis of the discussion indicates that that it was strongly focused on Costco's low prices, which many interpreted as an intervention into corrupted Icelandic business practices that prevailed after the crash, rather than seeing Costco as sign of Americanization or global imperialism.

\section{The Icelandic context}

Iceland had a long history of trade monopoly during the centuries when Iceland was under Danish rule and these monopolies continued, in a certain sense, through various restrictions and benefits to interest groups after independence in 1944. This developed within the banking industry; which, to a large degree, was owned by the government and was highly regulated (Loftsdóttir 2010). People in business often required access to political contacts in a landscape where pressure groups, usually affiliated to political parties, had access to money (Ásgeirsson 2008, 309-317), within an environment where currency restrictions were in place (Björnsson 2005). Few brands were usually available of each product domestically and they were expensive. For example, when one of us, Már, moved to the USA in 1987, he discovered that all the brands that he knew from Iceland were usually the most expensive ones.

The arrival of the store Bonus was important in shaping changes in the retail market, because it offered new brands at lower prices. The low prices in Bonus enabled the company to expand massively, making a store that began as a humble operation in 1992 into today's biggest retailer of consumer staples in Iceland. ${ }^{2}$ Also, following Iceland's entrance into the European Economic Area (EEA), currency restrictions in Iceland were abolished in 1995, making it easier to import items to Iceland without connections within the banks, thus not only adding more brands to the market, many of which were cheaper than those available before, but also increasing competition in prices. Another element that brought prices down following the EEA entrance was that the monopoly of many wholesalers diminished, and some stores began importing goods by themselves 
(Institute of Economic Studies of University of Iceland 2004). Despite these developments, food prices have remained high in Iceland. They were on average $50 \%$ higher in Iceland than in other European Union countries in 2001 (Institute of Economic Studies of University of Iceland 2004). That figure had only gone down to 46\% in 2016 (Eurostat database 2017).

The economic crash in Iceland created rippling effects in various sectors of its society, including national identity and in the economic and business landscape. Following the crash, the Icelandic currency lost more than half of its value in a few months, currency restrictions were again set in place and inflation skyrocketed. Jón Gunnar Bernburg captures well the severity of the crash when stating that it created a sense of "collective shared national disaster" $(2015,74)$. An economic bubble of this size was partly made possible by nationalistic rhetoric that emphasized the bankers and the businessmen, financed by the banks primarily, as Icelanders showed the "rest" of the world Iceland's compatibility with an increasingly globalized world (Loftsdóttir \& Mixa 2014). This glorification of bankers played on a persistent perception of Iceland as being a classless society (Oddsson 2010). This meant that anyone in Iceland could not only reflect themselves in the image of the banker, but also were shaped by long standing sense of smallness and Iceland's need to establish itself more strongly with more hegemonic powers within the world (Loftsdóttir 2015). The mobilization of the nationalistic framing of the economic adventure also took advantage of the strong binary opposition of us-Icelanders and them-foreigners (Hálfdánarson 2009; Loftsdóttir 2014), which to some extent can be seen as linked to Iceland as post-colony. This all worked toward rationalizing the enormous risks that were taken by the banking system with the benefits pocketed, to a large degree, by the biggest owners and directors of the banks, while the losses were borne by the public at large (Mixa 2016). Icelandic banks were furiously buying foreign banking entities and assets with the use of leverage (ibid.) in a similar vein as prior to the stock crashes in the USA in 1929 and 1987 (Nations 2017). When criticism of the risk to the Icelandic banking system began appearing in 2006 from foreign analysists, many stakeholders in the banking system, mobilized the dualistic discourse of us-them, reducing the criticism into jealously of "foreigners" toward the economic adventure (Loftsdóttir 2015).

During the first years after the crash in 2008, the discourse in Iceland strongly characterized fear for the future and a sense of belonging to a small and vulnerable nation. The Icesave debate in particular - involving disputes whether Iceland should pay losses from the internet bank Icesave in the UK and Holland - was particularly important in the continued reifications of "us" and "them" (Hálfdánarson 2009; Loftsdóttir 2014). Protests against corruption and leading political powers also became commonplace, culminating with protests in front of Parliament with protestors venting their fury against the government that allowed Icelandic banks to take such risks. The Special Investigation Commission report, focusing on the fall of the savings banks, showed massive corruption and nepotism in Icelandic politics and business life (Rannsóknarnefnd Alpingis 2014). However, there was also optimism and hope for a "new Iceland" right after the 
crash. The Panama files revelation in 2016 showed shockingly and clearly how profits from companies held by Icelanders continued to flow out of the country into offshore companies (Kristjánsson 2016). The protest that followed was probably the largest protest in Iceland with participants protesting corruption in general and demonstrating the lack of faith in politicians in Iceland (Bernburg 2016b). The shock of the Panama files revelations has to be contextualized in the long-standing suspicion in Iceland and even hostility toward foreign investments, coupled with the fear that profit will consequently leave the country (Jóhannesson 2008, 222). It can be suggested that the Panama files also indicated the loss of hope for a "new Iceland" of a more equal and democratic society.

\section{Costco in globalized markets}

Costco was formed in 1993 when Price Club, which began operations in 1976 and Costco, which began operations in 1983, merged into one company (Costco Wholesale n.d.). Despite its relatively short life span, Costco is already the second biggest retailer in the world in terms of revenue (NRF 2016), operating 736 warehouses world-wide, although about two-thirds of them are located within the United States (Costco Wholesale 2017). Costco is currently adding about half of its new stores in international markets (Costco Wholesale 2016, 2). Therefore, one can say that currently Costco is mainly a US retailer, but is transforming itself into an international one. Not only are the objects sold in Costco thus travelling around an interconnected landscape, but Costco itself becomes a travelling artifact (Della Dora 2009) or "things mobile" that is important to analytically engage with (Mavhunga, Cuvelier \& Pype 2016, 48).

Costco generally offers few brands of each item, often merely one brand of each product, usually high quality products, sometimes in addition to its own brand, Kirkland Signature, which usually are high quality products. In this sense, Costco can be seen as mirroring the limited choices that Icelandic consumers had until recently. Countering the few brands of each product, the store offers a wide range of products such as consumer staples, electronic devices of many sorts, kitchenware, gardening products, tires, optical and pharmaceutical items to name a few. The store also offers gasoline at many locations, often at prices lower than most other gasoline retailers do (Kline 2016).

Costco marks up its prices (the difference between the prices that Costco pays for its products and the retail price that Costco charges their customers) considerably less than most stores, ranging on average around $12-13 \%$, while Walmart and Target markup their prices around 25-26\% (Thomson Reuters Datastream database n.d.) ${ }^{3}$. The markup for Iceland's main retailer, Hagar, which operates low-cost stores called Bonus that mainly sell consumer staples and higher-class stores that are similar to Target, called Hagkaup, is also around $25 \%$ (ibid.).

This "wholesale" concept has exploded in terms of popularity during the last two decades, with such "wholesale" stores increasing sales tenfold from 1992 to 2013 (Soni 2016). Part of the increase Costco's sales can be attributed to the increase in new stores. Sales in each Costco store, however, also have increased steadily, with each store opened in 2009 selling, on average, items worth US\$100 million during the first year but US\$155 
million in 2015 (Costco Wholesale 2016, 1). According to its 2016 annual report, Costco expects to open 31 new stores in the coming 12 months.

The business paper Morgunblaðið first announced the possible arrival of Costco to Iceland on March 13, 2014. During the same month, representatives from Costco had met delegates from the Icelandic government to discuss a possible opening, enjoying a positive reception (Ægisson 2014). Costco formally announced on June 29, 2015 that it would open a store in Iceland, anticipated to open in 2016 (Morgunblaðið 2017b).

\section{The opening of Costco}

A build-up of excitement developed long before Costco opened. A year before the opening, individuals unrelated to the company opened the Facebook page Costco in Iceland (in Icelandic Costco á Íslandi), where it was claimed that the store would be opened in a few weeks and those who could guess where it would be located would win "a beach vacation" and gift certificate to use in the store (Sæmundsdóttir 2015). This was a hoax, possibly to make fun of the whole excitement surrounding Costco. Costco itself also seems to have actively worked toward stimulating the public imagination and thus facilitating the excitement of the opening of the store.

According to our informal interviews, those who worked in the store for the last days before it opened were strictly forbidden to take photos or to give any information about price-tags or products, which stimulated, in wider society, a great deal of guessing and excitement. Brett Vigelska, the CEO of Costco in Iceland, said in an interview that the Costco store in Iceland was a little bigger than a regular Costco store and more American in its design, because they wanted to respond positively to that Icelanders seemed to have affection for what was American and wanted to respond to that $(\mathrm{Mbl}$.is 2017). This is in line with previous studies in Iceland (Aðalsteinsson, Guðmundsdóttir \& Guðlaugsson 2011; Mixa \& Vaiman 2015; Ólafsson 2003) It is interesting that, in the light of this, the Costco store in Iceland is mainly controlled via Britain. A few days before the opening, the possible gas price also leaked out - intentionally or not - when a photo was circulated on the web showing the gas price on one of the pumps (Daðason 2017a). Costco claimed that this was just a test but the when the gasoline station opened afterwards this was the exact price (Jóhannsson \& Ólason 2017). The day before the opening, Costco invited selected people to an opening party, where Costco's CEO, President, and Costco's CEO in Europe were present (Morgunblaðið 2017c). The opening became a platform for desired information about prices in Costco, as was evident in the number of photos appearing on the internet of the price tags of various items in Costco, and phone calls that were intended to inform family and friends of the prices in Costco (Albertsdóttir 2017b). The American Embassy also published a video from the opening (Gunnarsson 2017).

Corporate multinational chains are, in fact, not new in Iceland but have a relatively long history. Kentucky Fried Chicken (now known as KFC), for example, has operated in Iceland since 1980. The arrival of other large chains has a reputation of being welcomed with great affection and excitement (Loftsdóttir 2014). The Prime Minister 
opened, for example, the chain McDonald's in 1994 with Iceland's political and business elite attending the event. Izberk-Bilgin (2008) points out the fact that multinational companies often hold a particular prestige for countries within the global south, where they are criticized as tools of American imperialism, simultaneously as being seen as a part of entrance into the "modern" world. ${ }^{4}$ Even though Iceland is not part of the global south, postcolonial anxieties have for a long time characterized Icelandic discussions. Kristín Loftsdóttir (2014) has maintained that the celebration of the McDonald's opening in Iceland in the mid-1990s can be seen as due to it being a symbolic entrance of Iceland as a former Danish colony experiencing itself, in a certain context, as on the borders of Europe - into a modern and international world. There are other more recent examples of great excitement concerning the opening of international chains, such as the opening of Dunkin' Donuts and the low budget clothing store Lindex. In both cases, long lines of people eager to enter the store at their grand openings were formed. When McDonald's closed in Iceland one year after the economic crash, the closing received great international coverage and it being reported on all over the world (Loftsdóttir 2014).

In spite of all the hype prior to the opening of the store, the opening morning of Costco probably did not attract as many people as the managers of Costco had hoped for. The journalists of Visir point out that fewer people were there when the store opened at nine, contextualizing it with the extensive crowds when other recent international firms "opened their doors" (Daðason 2017b). When one of us, Kristín, was there at the day of the opening, with her two girls tagging along as fieldwork assistants, the line was moderate both into the parking lot and into the store. They were quick to receive a shopping cart - almost twice the size of a regular one, probably to accommodate the size of packaging but also to normalize extensive consumption - and waited only briefly in line before entering the store. Inside the store, there was the ritual familiar to us from the US, where the membership card must be shown at the entrance. Long lines had formed in front of the desk where people could apply for membership cards. The store was large, but it was difficult to move around due to the number of people and the big shopping carts. Various items seemed to emphasize the store as bigger than life: The life-sized giraffe and elephant - that were shown in the newspapers - were clearly visible; huge teddy bears in a pile caused particular interest to our research assistants. Kristín told them that this is just a commercial hype; no one will buy them because one teddy bear will fill half of the average child's bedroom. It later turns out that she was completely wrong, with all of them sold out approximately a week later. When walking around the store, it is tempting to see Costco as a particular type of "travelling landscape" in Della Dora's $(2009$, 348) sense, inhabited by people, objects and diverse types of materiality, which becomes "mobilized in different cultural contexts"; then characterized by "huge-ness" as one of its key-metaphors. Around the store were food stations giving different food samples. Kristín stopped at one and when hearing that the woman was speaking English, she asked where the woman is from. "From England" the woman said and smiled gently, and Kristín replied "oh really". She smiled again and said: "We are all from there "luv". She then told her that they were from a special firm 
within Costco that were flown especially over to Iceland for the opening. They had arrived "yesterday" for the big opening and were then leaving later during the same night. When asked if Kristín can take a photo of her, she responded that the company strictly forbade that. Kristín asked at other food stations as well, and as before, received a polite response but no photos. In one place, Kristín talked to a young man who seemed to be one of the few Icelandic staff giving food samples and he told her, in Icelandic, with a mixture of irritation and finding it rather funny, that he was not even allowed to have his mother take a photo of him when she showed up with a camera. This a clear symbol of corporate, standardized business practices that appear foreign in the Icelandic environment.

It was still clear during the next few days that Costco was hugely popular, even though the opening was not characterized by the same kind of 'crazy' like atmosphere as the opening of other international chains. Two days after the opening, there was a national holiday in Iceland and the crowd began to arrive in earnest. It was so huge that people wanting to enter the store were chasing those who had done their shopping to obtain their carts (DV 2017a). Following this, the stream of people visiting the store was constant and conversations in the next days and weeks revolved around whether people had been to Costco yet and the media published an almost endless number of stories that in one way or another revolved around Costco. As the owner of another firm remarked, Costco did not need to buy any kind of advertisements they were so heavily published on an everyday basis by the media anyways (Ragnarsdóttir 2017a).

A plausible reason why the amount of people visiting Costco on the day of the opening was less than expected, and then much more shortly afterwards, is that people did not want to be photographed during such an event, keeping in mind photos in the local and international media of people jammed in crowds at other recent openings. The Icelandic consumers' sense of being incorporated in the world of mobile and moving images is reflected in their knowledge of that an Icelandic celebration of multinational corporations is likely to find its way into the press.

Only two weeks after the grand opening it was reported that Costco had sold 60,000 Icelandic membership cards (Jónsson 2017a), which translates to about 23\% of Iceland's population 18 years and older (Statistics Iceland n.d.-b). The traffic around the Costco store caused people living in the surrounding area difficulties in getting back home (Ragnarsdóttir 2017b). Another report followed at the end of August that estimated the figure of membership cards around 90,000, meaning that in only three months about $35 \%$ of Icelanders were Costco members (Halldórsson 2017a). That figure is well above the estimated average figure in the USA, which is around 26\% (Kalogeropoulos 2015). A month after the opening about half of the population in the capital area 18 years and older had visited Costco (Erlendsdóttir 2017a).

\section{Media discussion}

Articles about Costco analyzed for this paper were from the following web-based Icelandic newspapers: RÚV, Visir, Stundin, Vidskiptabladid, mbl.is, Pressan, Kjarninn and The 
Reykjavik Grapevine. Research was additionally conducted on google.is and a few articles were found in other webpage journals such as menn.is and íslensk-ameríska. The material was analyzed by open coding (Strauss \& Corbin 1998), where particular thematic categories were created from the analysis of data. The delimitation of data collection was that it contained discussion about the Costco opening, prioritizing material published the days before and after the opening. We also analyzed a few blogs that we found in relation to Costco, especially a page that was established after the opening of the Costco. Before we started collecting data, we were actually primarily interested in the international discussion about Costco, and as earlier stated, international companies in Iceland have gained immense international attention, the most extensive probably being the closing of McDonald's in Iceland in 2009. To our surprise, the international media showed little interest in the opening of Costco, while the Icelandic discussions were even more extensive than we estimated before our data gathering. Our analysis is based on active interplay of theory and data collection (Strauss \& Corbin 1998,12-13), which has long history in anthropology, and where we did not decide on rigid categories of analysis in advance but constantly questioned the categorizes during collection and analysis of data (Wood \& Kroger 2000, 29). The analysis here is notably not quantitative analysis of the collected materials (which often characterizes grounded theory and open coding), meaning that we do not seek to qualify the numbers of themes that we identified in different articles or number of times certain concepts appear, but consists rather as a qualitative analysis that attempts to capture themes that were seen as relevant in Iceland when Costco opened.

We start the discussion by outlining general aspects of the themes that emerged and then discuss more specifically the most salient themes emerging in the discussion. Prior to the opening of Costco, there was discussion on the effects on the Icelandic markets in general. Some ministers stressed that it was positive to have international firms investing in Iceland, which would increase diversity and competition (RÚV 2014), while others were concerned that large chains would push out smaller stores and thus reduce diversity (Morgunblaðið 2014). The discussion and excitement about the opening of Costco was, however, not about the global or imperial characteristics of the firm, neither so much about the products that were being offered, but rather centered strongly on their price as compared to other similar products in the Icelandic market.

We have classified the articles into three themes that we saw as most salient during the opening. They were discussions regarding 1) Costco selling gasoline, 2) Costco's influence on Icelandic markets, 3) The effect Costco's prices had for general consumers. These three themes intersect strongly, but for the clarity of the argument we will treat them as separate and then in the discussion section show more of their interconnectivity and differences. To us, these three themes reflect how Costco was brought into a very specific Icelandic discussion that has to be positioned within post-crash concerns in Iceland where corruption and injustice became a focal theme (Johnson, Einarsdóttir \& Pétursdóttir 2013; Ólafsson 2014), thus reflecting Tsing's use of the concept "friction" to capture the unexpected outcomes of globalization processes. Simultaneously, how- 
ever, while taking forms specific to Iceland, these concerns should not be fully perceived as localized as they are a part of wider transnational concerns that became particularly intensified after more globalized economic crisis (see Moore 2017 on transnational concern).

\subsection{Inexpensive gasoline}

The discussion regarding gasoline prices was the first major discussion of a particular Costco product. Prior to the opening, the main question was whether the markup of gasoline prices would be similar to the UK, where the headquarters of the Icelandic Costco are, or reflect more the prices in Iceland (Mixa 2017). Four days before the grand opening, the Costco signs by the gasoline station showed prices at 169.9 ISK per liter. This became an instant discussion in the media, with the assistant CEO of Costco interviewed about this, who said that Costco had made no decision regarding the price structure yet and these were simply tests (Daðason 2017a). This statement fueled the fire of anticipation of Costco's opening. Two days later, when the Costco gasoline station formally opened, the gasoline price was the same as the "test" price. The price was in line with the markup in the UK Costco stores and thus a much lower price than average Icelandic gasoline prices, which were around 198-199 ISK at most other gasoline stations (Albertsdóttir 2017c).

This caused, to say the least, a major stir as is vividly reflected in the media discussion. The director of the Icelandic Automobile Association maintained that the markup in Iceland was much higher than in the surrounding countries, stating that this would have an enormous effect on the oligopolistic Icelandic market (DV 2017b). Interviews were taken with the CEOs of the three major gasoline companies in Iceland. While one CEO stated that his company would monitor the effects on the market (Arnarsson 2017a), two CEOs stated that they would not change their price structure, with one of them maintaining that customers would rather prefer service and convenience than a few percent difference in price (Sigpórsdóttir 2017). Many bloggers asked what services the three major companies really offered, with one blogger, Benedikt, stating: "What service?? One always has to pump oneself everywhere and everything is set up in a way that the customer takes care of himself and shows up at the register. At Costco, there is always an employee by the pumps" (Clausen 2017). The CEOs even suggested that the prices in Costco were loss-leading prices, with Costco's CEO, Brett Vigelskas, denying this (Arnarsson 2017b).

These discourses about gasoline prices reflect how in the days leading up to the grand opening, gasoline prices were a "watercooler" topic at many workplaces. This possibly opened the gates to public discussion about the gasoline in Costco going into strange dimensions. Some maintained that the gasoline had additives that made it better for the engine and increase mileage (Valgerðardóttir 2017), and the gasoline being even better than other gasoline in Iceland (Clausen 2017). The media reported that it is true that Costco add some additives to the gasoline (Valgerðardóttir 2017), but it is common among gasoline re-sellers (Jónsson 2017b). The discussion spread to environmental is- 
sues, with some environmentalists maintaining that low prices increased the inclination to use gasoline and thus pollute the environment even more (Bjarnar 2017a).

The success of the gasoline station has been enormous. By August it was estimated that the market share of the sole gasoline station owned by Costco was 15\% of all gasoline sold in the capital area (Arnarsson 2017). Long lines at the gasoline station soon showed the popularity of the station (Morgunblaðið 2017d), with plans to set up an additional four pumps there in place only three weeks after the opening, in an attempt to satisfy the demand (Morgunblaðið 2017e).

\subsection{Effects on prices for general consumers}

During the opening party people in Iceland began comparing Costco prices to prices in other stores, with the media posting pictures of various items and the price tags (Morgunblaðið 2017f). A news article with the headline "Icelanders are extremely interested about the pricing at Costco," captures well the salience of this issue during the opening of Costco (Pálsson 2017). The media interviewed satisfied customers (Albertsdóttir 2017d) and showed pictures of their shopping carts. In most cases the products are everyday products, such as food items or other items that individuals are likely to buy to use for themselves. One customer stated, for example: "I had looked at other places and this is by far the best price so I took it. I had to renew the saw and here was the best price so this was no question" (Jónsson 2017c). The price of half a liter of regular water was also commented on and then pointed out that it was five kronur lower than the price people receive at recycling terminals (Guðmundsson 2017). Costco later announced that the low price was a mistake, since the store had forgot to consider the recycling fee when pricing the water (Jónsson 2017d).

The articles published at Costco's opening clearly reflect that many believed that because of Costco, food prices would become lower (Sigurðardóttir 2017). The emphasis on Costco as having positive effects on food prices for consumers intersected with discussions about retailers having overcharged the Icelandic public for a long time (Albertsdóttir 2017e; Miðjan 2017a; Halldórsson 2017; Eyjan 2017b) within an oligopoly retail landscape in many areas (Miðjan 2017b). The high numbers of customers were thus seen by some as a sign of rebellion against the high prices that Icelanders had to tolerate for a long time (Miðjan 2017c). There were even reports of people in the Keflavik area arranging "field trips" to Costco, to make sure their local stores would receive less business from them, having charged such high prices for many years.

Not everyone shared this view, with the chairperson of the commerce employee's union stating that the trend of lower prices in Iceland was more due to online shopping than Costco (Miðjan 2017d). The chairperson of the Federation of Trade and Services said that he welcomed the arrival of Costco but thought that the discussion was not objective, talking about usury pricing and domestic retailers as criminals (Hilmarsdóttir 2017). The owner of Kostur - a retailer that had followed Costco's business model to some extent and even sold Costco's Kirkland Signature products - took a similar stance. He said that the discussion was in a somewhat wrong direction stating that; "it is not 
possible to expect the grocer with a corner shop could receive the same prices as the second largest retailer in the world."'5 (Morgunblaðið 2017g). The CEO of Bonus said he was sad because of the negative news regarding his company, stating that even if Bonus would cease marking up prices on their items, nothing would change. The high prices in Iceland were not due to pricing at Bonus (Erlendsdóttir 2017b).

A Facebook group, "Bought in Costco - Pictures and Prices", ${ }^{6}$ is probably the best example of how strongly centered the discussion was on the prices of everyday items. It was established to follow the pricing of goods in Costco and within 24 hours just over 10 thousand people, or about $3 \%$ of the Icelandic population, had joined the group (DV 2017c). Almost a week later, the members of the group totaled almost 70 thousand with Costco appearing as the main discussion subject among the population (Eyjan 2017a), and soon became the biggest Facebook group in Iceland, reaching 85 thousand members during the beginning of July (Bjarnar 2017b). It was newsworthy that the administrator of the group had not herself gone to Costco, living far away, but had simply formed the group because of her curiosity and wanted to be better able to organize her shopping (Ólafsdóttir 2017).

\subsection{The influence on Icelandic markets}

It is perhaps not surprising considering how much of the discussion on Costco revolved around prices and savings that many articles discussed the effects on the Icelandic retail market as a whole. In some cases, the discussion is more indirect, focusing on the great numbers of people shopping at Costco while parts of the discussion revolved around more emotional statements that this would change the market as a whole.

The media reported on the fast-growing membership of Costco, either by directly speculating about the effect on Icelandic markets or implicitly (Jónsson 2017e), but there was also a lot of discussion about its popularity, which seemed to have surpassed expectations. Less than three weeks after the grand opening, images started to appear in the media and elsewhere that showed many shelves in Costco as empty or close to being so (Ragnarsdóttir 2017c), sending further strong messages of cheap prices at Costco. The immense amount of shopping at Costco even had the research department of Arion bank suggesting that the total spending in Iceland during the second quarter of 2017, which was relatively higher than previously estimated, was possibly due to the arrival of Costco (Arion banki 2017). The key issue here is that prior to Costco opening and after, intense discussion and speculation existed in regard to if (before the opening) and then simply how Costco would change the Icelandic economic scene. In the material that we found, different journals primarily conceptualize this change in terms of what this would mean for other retailers or the possible and then usually positive effects on Icelandic consumers. These articles both involved news stories and interviews with prominent people within the Icelandic business community, but the salience here is that they work together in creating a sense of Costco as important in radically changing the retail market of Iceland. Vísir published, for example, a short discussion in June 2016, under the heading "Costco will cause havoc in the Icelandic market," (Bjarnar 2016) 
where it is stated that Costco will have an effect on the Icelandic market (which was not obvious at that point to the general population) and Kjarninn in May 2017 "The giant Costco shakes up the Icelandic market," (Halldórsson 2017b) where it is no longer a question of whether Costco will shake up the retail market.

The editor of one journal captures the emotional side of the discussion of the effects on Costco on Icelandic markets well when writing under the heading "The Icelandic business mafia cannot sleep due to worries about Costco":

Is it really so strange that the Icelandic nation celebrates? That it lets itself stand in line? Icelandic consumers have always had to endure extreme markups - everyone knows that who have given retail prices any thought. Here Icelandic merchants within the power of oligopoly and free trade fleeced consumers as they wish, now screaming as if they have been stabbed when the giant Costco, which is NOT owned by Icelanders and can NOT be controlled, opens here a supermarket with big items and lower prices than have ever been seen here. (Porsteinsdóttir 2017). ${ }^{9}$

One can see a somewhat similar emphasis in different blogs where Costco is seen as "hopefully" ending corruption persistent in Icelandic markets. In this comment written in a news story talking about the lines on the second day of Costco, the author expresses the need to get "foreign" companies to change the business environment in Iceland. The author says:

This immense success of Costco will hopefully lead to other foreign companies seeing it feasible coming here...it is hopeless to engage in normal business transactions with Icelandic retailers where the high markups engulf everything, the government disposes import duties and fees, the retailer steals them...this is how Icelanders work, most of them.... and if they do not stop then they will be forced to stop by going bankrupt... [they] cannot continue simply obtaining a new social security number and continue the usury practices. Game over for high markups in Iceland thank you (Bjarnar 2017c). ${ }^{10}$

A comic published in Fréttablaðið (2017) a few months after the Costco opening also captures clearly this discussion. It depicts four men sitting in a hot-tub, each one with a cap which is marked with a name of a main retailer company. One of them says "Is this Costco dude going to be there endlessly circling around in the swimming pool?" The hot-tub itself is the Icelandic retail market, labeled "Icelandic competition, 37 degrees", thus signaling that the Icelandic competition is in fact just a cozy collaboration between main actors at a nice "temperature" agreed by everyone. They are, according to the comic, just waiting for Costco to join the group. 
Figure 1. Icelandic competition, 37 degrees

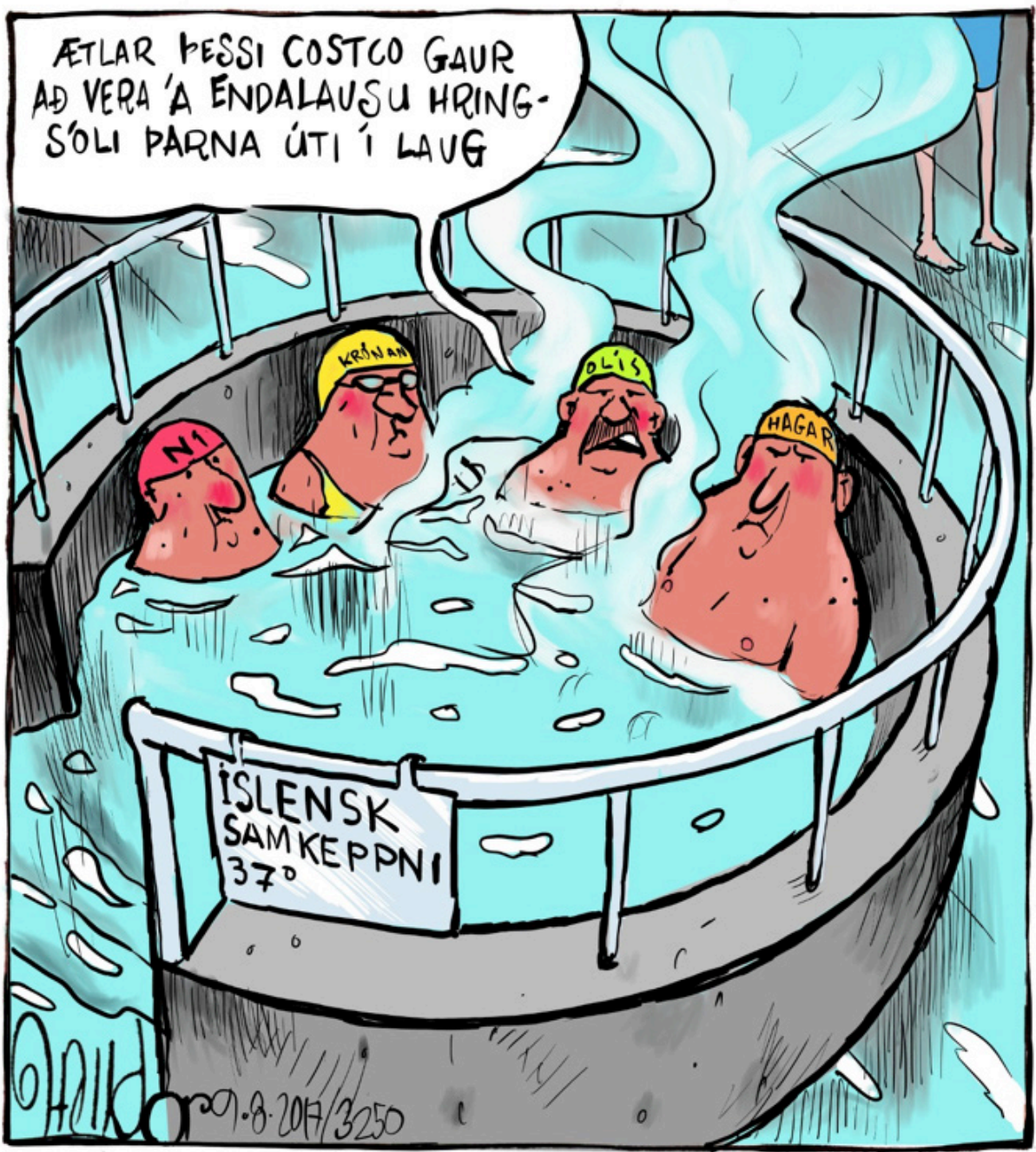

The image is used with kind permission from artist Halldór Baldursson

\section{Discussion}

Looking at the discussion surrounding the opening of the Costco as a whole, it has revolved very strongly around prices to consumers and changes that Costco would bring to the retail landscape in Iceland. Costco, however, is nevertheless a US retailer that is slowly changing itself into an international retailer with its more global expansion. The large quantities of each product and the enormous size of some individual products can be read as symbolic of extensive consumerism, that often is associated with the US, especially, as noted below, when considering that many of those who actually shop at Costco are not retailers but regular people. 
Viewed in such a way, Costco can be seen as symbolic of globalization as an Americanization. It is, however, difficult to find articles or discussions that position Costco within the framework of negative imperialistic effects of large corporations or homogenizing effects on Icelandic society and culture, thus indicating blank spaces or silences in Kutsche's (1998) sense. In contrast, when McDonald's opened in 1994, there were concerns with the rights and salaries of those working there (Loftsdóttir 2014), something that is almost non-existent in the discussion of Costco. While there were voices that raised concerns about Costco in the sense of the foreign ownership of the firm and what that would mean in terms of Iceland, these were quite marginal in the discussion. Two politicians, generally considered being left wing, were rather critical of the company's arrival to Iceland while right wing politicians were more positive (Morgunblaðið 2017h; DV 2017d; RÚV 2014). After Costco opened, such dualistic division into left and right - where one arm generally speaks against wide open free markets, the other for it - seemed to blur and Costco was brought into an ongoing "post-crash" discourse revolving around corrupted Icelandic elites and even in some sense the betrayal of the Icelandic public to monetary forces. The so called "locals" in theories of globalization are, as argued by Haugerud (2003), historical products themselves, which both shape actively the understanding of global processes while simultaneously being shaped by them (p. 64). In the case of Iceland, Icelandic discussions thus draw from the recent economic crash and its aftermath to understand and engage with other globalized events. Costco was seen by many as important to improve the life of regular people. Tsing's (2005) metaphor of friction draws out importantly how globalization - consisting of flow of ideas, people, and cultural artifacts between and across spaces - creates something that is difficult to predict in advance. Costco as a "travelling landscape" (Della Dora 2009) - consisting of often over-sized products, its size, layout of store and the people - becomes meaningful in Iceland at the stores opening partly through the prism of post-crash discussion.

These "blank spaces" in the discussion about Costco opening are, however, surprising in the context of the post-crash criticism. While the profits of many retailers in Iceland are taxed within Iceland, Costco's profits probably are not. Costco can transfer its profits to offshore jurisdictions (where taxes are non-existent) or pay them in USA, by using a simple scheme described by Shaxson (2012) as being the most common way of multi-national firms. It involves the parent company lending the subsidiary money, making sure that interest costs offset net income figures, meaning that the profits are realized in tax havens. This is interesting considering the furor following the Panama files, involving Icelanders transferring their profits abroad to avoid paying taxes in Iceland. While tax-evading practices may have been common among some companies in Iceland for a long time (Vilhjálmsson 2015), people have until recently been left in the dark of off-shore tax evading schemes. Jón Pór Helgason (2014) did point out Costco's possibilities of not paying taxes in Iceland, yet this issue has mostly been muted, but the public at that point in time had very little knowledge about the issue. Additionally, 
Hagar, the biggest retailer in Iceland, is mostly owned by Icelandic pension funds, who had at least a 54.6\% ownership in the company on November 9, 2017, judging from the 20 biggest owners of Hagar (2017). The market value of Hagar fell 20 billion ISK during the months following the grand opening of Costco. Icelandic pensioners are thus losing future cash flows with the added popularity of Costco.

While our goal here is not to assess if Costco has and will lead to a change in consumer prices, it can be pointed out that this does seems to be the case. The effects in Iceland are, however, noticeably hard to detect precisely, partly due to that during the leading 12-24 months before Costco opened its doors in Iceland, the ISK appreciated a great deal against most currencies, making imported products far cheaper. There are a few examples of what many have called the so-called "Costco effect". A major tire distributor lowered its prices $40 \%$ in April and advertised this new price a great deal. While the company stated various reasons for the lower prices, for example the strengthening of the ISK, many believed that the company was simply responding to the arrival of Costco (Vísir 2017). It has emerged that tires, including changing them at Costco, cost almost 50\% less than at other competitors (Miðjan 2017e). According to the financial data firm, Meniga, Costco appeared to have a higher turnover than Bonus, but this was probably not entirely comparable since Costco sells other things than consumer staples, which cost much more than daily items (Halldórsson 2017b). Costco's market share during the first few days after its opening was estimated to be at $32 \%$, even higher than the $28 \%$ market share of Bonus stores, which have 32 stores (ibid.) and had a $39-40 \%$ market share in Iceland in 2015 (Samkeppniseftirlitið 2015).

Finally, it should be emphasized that only a few months after Costco's opening (after we wrote the first draft of this article), this somewhat celebratory discussion of Costco seemed to change with a much more critical discussion appearing somewhat suddenly on issues such as bad treatments of employers of Costco (Clausen \& Guðnason 2017). Also, some questioned whether Costco's prices were actually lower (Jónsson 2017), with some maintaining was simply due to Costco having forced prices down in other stores (Viðskiptablaðið 2017).

\section{Conclusion}

In this article, we have discussed the arrival of Costco to Iceland in 2017 using insights from theories of globalization and mobility to understand better how this multinational company became a focal point in intersecting discourses about improved living standards in Iceland. The opening of Costco - this multinational company that not only represents globalization but was, even in Iceland, built more in the vein of US stores, as opposed to European versions - has become, in a sense, an organizing metaphor to talk about corrupted business elites in Iceland and high prices to consumers. The economic crash and its aftermath thus shaped how Costco was viewed in Iceland. 


\section{Acknowledgements}

This paper is a part of the project of Excellence, Mobility and Transnational Iceland, funded by Rannís (Icelandic Center for Research), grant number: 163350-051. Special thanks to Sanna Magdalena Mörtudóttur, M.A. student in Anthropology at the University of Iceland for her assistance in data gathering.

\section{Notes}

1 In Icelandic "Sjáið myndirnar úr Costco"

2 Bonus is now owned by the holding company Hagar, which is the only listed retailer in Iceland. Kronan is also a major retailer in the area but its mother company, Festi, is not listed.

3 Thomson Reuters Datastream database shows historical differences between costs and revenue figures derived from the annual reports of these companies and authors' calculations.

4 This reception of McDonald's in the global south is obviously not uniform: in Bolivia the brand failed due to lack of interest (Foxnews.com 2013), which affirms the complex ways in which multinational firms such as McDonald's intersects with local understandings (Turner 2003).

5 In Icelandic: Рað er ekki hægt að ætlast til pess að kaupmaðurinn á horninu geti fengið sömu verð og næststærsti smásali í heiminum.

6 In Icelandic: "Keypt í Costco - Myndir og verð."

7 In Icelandic: "Costco mun umturna íslenskum markaði"

8 In Icelandic: "Risinn Costco hristir upp í íslenskum markaði"

9 Our translation from the original text.

10 Our translation from the original text.

\section{References}

Aðalsteinsson, G.D., Guðmundsdóttir, S., and Guðlaugsson, P.Ö. (2011). “Íslensk pjóðmenning í ljósi menningarvídda Hofstede" [Icelandic Cultural Nationality within Hofstede's Culture Dimensions]. Icelandic Review of Politics and Administration, 7(2), 353-368.

Agnarsdóttir, A. (2008). "The Danish Empire: The Special Case of Iceland”, in M.N. Harris and C. Lévai (eds.), Europe and its Empires (pp. 59-84). Pisa: Pisa University Press.

Albertsdóttir, A. (2017a). "Við erum að dýfa tánum í vatnið” Morgunblađið, 9 February.

Albertsdóttir, A. (2017b). "Með stjörnur í augunum í Costco” Morgunblaðid, 22 May.

Albertsdóttir, A. (2017c). “Costco selur lítrann af bensíni á 169,9 krónur” Morgunbladio, 21 May.

Albertsdóttir, A. (2017d). “„Maður hefur ekki séð svona verð áður“"” Morgunblaðið, 24 May.

Albertsdóttir, A. (2017e). "Staðfestir hversu stórfellt okrið hefur verið” Morgunblaðið, 11 April.

Arion banki (2017, September). "Einkaneysluhagvöxtur mættur á svæðið - 3,4\% hagvöxtur á 2F". Viewed 9 September 2017 at https://www.arionbanki.is/markadir/greiningardeild/greiningardeildallar-frettir/2017/09/08/Einkaneysluhagvoxtur-maettur-a-svaedid-3-4-voxtur-landsframleidslu-a$2 \mathrm{~F} /$

Arnarson, B. (2017). "Costco selur sjötta hvern bensíndropa” Morgunblaðið, 4 April.

Arnarsson, S. (2017a). “Titringur á eldsneytismarkaði vegna lags verðs hjá Costco” Vísir, 22 May.

Arnarsson, S. (2017b). "Segjast ekki ætla að keppa við Costco" Vísir, 23 May.

Ásgeirsson, J.F. (2008). Бjóð í hafti: Saga verslunarfjötra á Íslandi 1930-1960. Reykjavík: Bókafélagið Ugla ehf.

Bernburg, J.G. (2015). "Overthrowing the Government”, in E.P. Durrenberger and G. Pálsson (eds.), Gambling Dept: Iceland's Rise and Fall in the Global Economy (pp. 63-78). Boulder: University Press of Colorado. 


\section{STJÓRNMÁL $\&$ \\ STJÓRNSÝSLA}

Bernburg, J.G. (2016). "Mótmælin og stóra samhengið” Kjarninn, 15 April.

Bjarnar, J. (2016). "Costco mun umturna íslenskum markaði” Visir, 6 June.

Bjarnar, J. (2017a). "Niðurgreiða bensín til að lokka fólk í búðina” Vísir, 22 May.

Bjarnar, J. (2017b). "Hrellir hins stranga stjórnanda Costco-hópsins" Vísir, 4 July.

Bjarnar, J. (2017c). "Raðirnar í Costco náđu enda á milli” Visir, 19 June.

Bjarnason, D. (2017). “Ófyrirséðar afleiðingar af Costco” Morgunblađid, 24 August.

Björnsson, L. (2005). Saga verslunar á Íslandi (2 $2^{\text {nd }}$ ed.). Reykjavík: Viðskiptaráðuneytið.

Bordi, I. V. (2006). “The "Authentic” Taco and Peasant Women:”, Culture \& Agriculture 28(2), 97-107.

Clausen, K. (2017). "Costco-bensínið dugar ekki betur” DV, 23 June.

Clausen, K., and Guðnason, K.H. (2017). Costco: Matarsóun og slæm framkoma yfirmanna. DV, October 13 .

Costco Wholesale (n.d.). "About Us". Viewed 2 July 2017 at https://www.costco.com/about.html

Costco Wholesale (2016). Annual Report. Viewed 2 July 2017 at http://phx.corporate-ir.net/phoenix. zhtml?c=83830\&p=irol-reportsannual

Costco Wholesale (2017, August). "Costco Wholesale Corporation Announces Death of Chairman Jeff Brotman". Viewed 1 September 2017 at http://investor.costco.com/mobile.view?c $=83830 \& v=20$ $3 \& \mathrm{~d}=1 \& \mathrm{id}=2290812$

Daðason, K.T. (2017a). "Costco sýnir bensínlítrann á 170 krónur” Visir, 19 May.

Daðason, K.T. (2017b). "Fjölmenni beið pess að Costco opnaði á degi tvö" Visir, 24 May.

Della Dora, V. (2009). “Travelling landscape-objects”, Progress in Human Geography 33(3), 334-354.

DV (2017a). “Tryllingur í Costco : „Detta var nú meiri klikkunin“. - Sjáðu myndirnar”, 25 May.

DV (2017b). “Titringur vegna eldsneytisverðs Costco: „Detta verð mun hafa gífurleg áhrif á klassískum helsjúkum fákeppnismarkaði“", 22 May.

DV (2017c). “Íslenski Facebook-hópurinn sem allir vilja ganga í: „Petta er mín uppáhaldsbúð!‘’”, 24 May.

DV (2017d). “Sóley Tómasdóttir sér ekkert jákvætt við komu Costco: „Vond áhrif á vöruverð, skipulag, samgönguhætti"', 24 May.

Einarsson, E.B. (2006). "Fiskurinn eða fullveldið? Hvað skýrir ólík tengsl Íslands og hinna Norðurlandanna við Evrópusamrunann?”, Stjórnmál og stjórnsýsla 2(1), 95-128.

Erlendsdóttir, D.H. (2017a). "Helmingur Reykvíkinga hefur farið í Costco" RÚV, 16 June.

Erlendsdóttir, D.H. (2017b). "Costco hefur áhrif á Bónus" RÚV, 2 June.

Eyjan (2017a). "Meira en fimmtungur pjóðarinnar á Costco vef”, 30 May.

Eyjan (2017b). "Okrað á okkur í langan tíma", 9 July.

Eurostat database (2017, June). "File: Graph1Price level index for food and non-alcoholic beverages, 2016 (EU-28=100).png". Viewed 1 September 2017 at http://ec.europa.eu/eurostat/statisticseexplained/index.php/File:Graph1Price_level_index_for_food_and_non-alcoholic_beverages,_2016_(EU-28\%3D100).png

Guðmundsson, H. (2017). "Vatn Costco ódýrara en skilagjald flöskunnar” Vísir, 24 May. Hagar (2017). "Hluthafalisti - 20 stærstu". Viewed 15 November 2017 at http://www.hagar.is/hluthafaupplysingar/hluthafalisti---20-staerstu/

Gunnarsson, O.Æ. (2017). "Fáðu pér göngutúr um Costco" Vísir, 22 May.

Halldórsson, Í. (2017). "Beðið eftir Café Costco" Visir, 6 June.

Halldórsson, J.H. (2017a). “Tíundi hver ætlar ekki í verslunarferð í Costco” Visir, 2 September.

Halldórsson, J.H. (2017b). "Velta Costco meiri en Bónuss" Vísir, 2 June.

Halldórsson, M. (2017). "Risinn Costco hristir upp í markaðnum” Kjarninn, 22 May.

Haugerud, A. (2003) "The Disappearing Local”, in A. Mirapassi, A. Basu, and F. Weaver (eds.), Localizing Knowledge in a Globalized World (pp. 60-81). New York: Syracuse University Press.

Hilmarsdóttir, S.K. (2017). "Finnst ómálefnalegt að tala um okur og glæpamenn í tengslum við Costco" Visir, 31 May.

Hálfdánarson, G. (2009). “Hver erum við? Um „okkur”, „hin”, Icesave og ábyrgð pjóðar”, Saga XLVII, 158-174. 
Helgason, J.P. (2014). “Hagar gegn Costco - er jafnt gefið?” Vísir, 8 July.

Icelandic Tourist Board (2017). "International visitors to Iceland 2016". Viewed 14 November 2017 at https://www.ferdamalastofa.is/en/moya/news/international-visitors-to-iceland-2016

Inda, J.X., and Rosaldo, R. (2008). "Tracking global flows", in J.X. Inda and R. Roslaldo (eds.), The anthropology of globalization: A reader (pp. 3-46). Oxford: Blackwell.

Institute of Economic Studies of University of Iceland (1999). "Skýrsla nr. C99:08 Samanburður lífskjara á Íslandi og í Danmörku. Skýrsla til Verzlunarmannafélags Reykjavíkur”. Viewed 15 November 2017 at_https://rafhladan.is/bitstream/handle/10802/5057/C9808-Samanburdur-lifskjara-a-Islandi-og-i-Danmorku.pdf?sequence $=1$

Institute of Economic Studies of University of Iceland (2004). "Samanburður á matvælaverði á Íslandi, Norðurlöndum og ríkjum Evrópusambandsins Skýrsla til forsætisráðuneytisins”. Viewed 1 September 2017 at https://rafhladan.is/bitstream/handle/10802/6287/C0403-Samanburdur-amatvaelaverdi-a-Islandi-Nordurlondum-og-rikjum-Evropusambandsins.pdf? sequence $=1$

Izberk-Bilgin, E. (2008). "When Starbucks meets Turkish coffee: cultural imperialism and Islamist as 'other' discourses of consumer resistance", Advances in Consumer Research 35, 808-9.

Johnson, J.E., Einarsdóttir, D., and Pétursdóttir, G.M. (2013). "A Feminist Theory of Corruption: Lessons from Iceland”, Politics \& Gender 9, 174-206. doi:10.1017/S1743923X13000032.

Jóhannsson, J.K., and Ólason, S.K. (2017). "Bensínstöð Costco opnuð: Selja bensín á 169,9 krónur" Visir, 21 May.

Jóhannesson, S. (2008). "Stóriðja og hlutverk hins opinbera: Hver er ávinningur Íslendinga af fyrirgreiðslu við erlenda fjárfesta?”, in Valur Ingimundarson (ed.), Uppbrot bugmyndakerfis: endurmótun islenskerar utanríkisstefnu 1991-2007, 221-251. Reykjavík: Hið íslenska bókmenntafélag.

Jónsson, S.M. (2017) “Matarkarfan í Costco hækkað verulega á fáeinum mánuðum.” Vísir, November, 3. Jónsson, S.Ó. (2017a). "Einn af hverjum fjórum meðlimur í Costco” Vísir, 7 June.

Jónsson, S.Ó. (2017b). "Costco bensínið er lyfleysa” Vísir, 28 June.

Jónsson, S. Ó. (2017c). "Kíkt í körfur í Costco” Vísir, 23 May.

Jónsson, S.Ó. (2017d). "Costco segir lága verðið hafa verið mistök” Vísir, 9 June.

Jónsson, S.Ó. (2017e). "Einn af hverjum fjórum meðlimur í Costco" Visir, 7 June.

Kalogeropoulos, D. (2015). "Just How Many Americans Are Costco Wholesale Corporation Members?” The Motley Fool, 22 June. Viewed 6 September 2017 at https://www.fool.com/investing/ general/2015/06/22/just-how-many-americans-are-costco-wholesale-corpo.aspx.

Kline, D.B. (2016). "Is It Worth Paying $\$ 55$ for a Costco Membership Just to Buy Gas? Weighing the factors" The Motley Fool, 9 June. Viewed 10 November 2017 at https://www.fool.com/investing/ general/2016/06/09/is-it-worth-paying-55-for-a-costco-membership-just.aspx

Kristjánsson, J.K. (2016). "What! You must be joking? Kveðja frá ritstjóra Reykjavik Media,” Reykjavík Media. Viewed 2 February 2017 at http://rme.is/pistlar/what-you-must-be-joking/

Kutsche, P. (1998). Field Ethnography: A Manual for Doing Cultural Anthropology. Pearson College Division.

Loftsdóttir, K. (2010). The loss of innocence: The Icelandic financial crisis and colonial past, Anthropology Today 26(6), 9-13.

Loftsdóttir, K. (2014). Building on Iceland's “Good Reputation”: Icesave, Crisis and Affective National Identities. Ethnos 81(2), 338-363. doi: 10.1080/00141844.2014.931327

Loftsdóttir, K. (2015). ““'The Danes Don’t Get This”: The Economic Crash and Icelandic Postcolonial Engagements", National Identities. doi: 10.1080/14608944.2016.1095491

Loftsdóttir, K., and Mixa, M.W. (2014). "Bankar í ljóma pjóðernishyggju: efnahagshrunið, hnattvæðing og menning”, Skirnir 188, 91-115.

Loftsdóttir, K., and Skaptadóttir, U.D. (2016). "Ísland í heiminum og heimurinn í Íslandi”, in K. Loftsdóttir, U.D. Skaptadóttir and A.L. Rúnarsdóttir (eds.), Ísland í heiminum, heimurinn í Íslandi. Reykjavík: National Museum of Iceland.

Lund, K.A., and Jóhannesson, G.T. (2014). "Moving places: Multiple temporalities of a peripheral tourism destination", Scandinavian Journal of Hospitality and Tourism 14(4), 441-459. 


\section{STJÓRNMÁL \& \\ STJÓRNSÝSLA}

Lund, K.A., Kjartansdóttir, K., and Loftsdóttir, K. (2017). “"Puffin love”: Performing and creating Arctic landscapes in Iceland through souvenirs", Tourist Studies. doi: 10.1177/1468797617722353

Mavhunga, C.C., Cuvelier, J., and Pype, K. (2016). ““"Containers, Carriers, Vehicles”: Three Views of Mobility from Africa", Transfers 6(2), 43-53.

Mbl.is (2017). “Costco mun selja áfengi”, 18 May. Viewed 22 May at http://www.mbl.is/vidskipti/frettir/2017/05/18/costco_mun_selja_afengi/

Miðjan (2017a). "Biðja Guð að blessa Costco", 9 June.

Miðjan (2017b). "Berskjaldaðir neytendur eygja von í Costco", 4 July.

Miðjan (2017c). "Kröftug mótmæli í Costco", 3 July.

Miðjan (2017d). "Ekki Costco að pakka”, 12 June.

Miðjan (2017e). "Costco 50\% ódýrari”, 22 May.

Ministry of Education (2005). "Skýrsla nefndar menntamálaráðherra um íslenska fjölmiðla". Viewed 1 September 2017 at http://brunnur.stjr.is/mrn/utgafuskra/utgafa.nsf/xsp/.ibmmodres/domino/ OpenAttachment/mrn/utgafuskra/utgafa.nsf/6360E328071A0E50002576F00058DAC3/Attachment/fjolmidlanefnd.pdf

Mixa, M.W. (2016). "The Icelandic bubble and beyond: investment lessons from history and cultural effects". PhD thesis at the Reykjavík University. Viewed 14 September 2017 at http://hdl.handle. net/1946/26440.

Mixa, M.W. (2017). “Costco verður Wal-mart Íslands”. Viewed August 192017 at http:/ / marmixa.blog. is/blog/marmixa/entry/2196149/

Mixa, M.W., and Vaiman, V. (2015). "Individualistic Vikings: Culture, economics \& Iceland”, Icelandic Review of Politics \& Administration 11(2), 355-374.

Moore, H.L. (2004). "Global anxieties: concept-metaphors and pre-theoretical commitments in anthropology", Anthropological theory 4(1), 71-88.

Moore, T. (2017). "The Transformation of the Occusphere”, Social Identities 23(6), 674-687.

Morgunblaðið (2014). "Próunin ekki stuðlað að fjölbreytni”, 5 July.

Morgunblaðið (2017a). "Sjáið myndirnar úr Costco”, 23 May.

Morgunblaðið (2017b). "Costco gengur frá samningum”, 29 June.

Morgunblaðið (2017c). "Bannað að versla og ekkert áfengi”, 17 May.

Morgunblaðið (2017d). "Bensínstöð Costco starfar við hámarksgetu”, 20 June.

Morgunblaðið (2017e). "Costco fær að stækka bensínstöðina”, 27 June.

Morgunblaðið (2017f). "Svona er verðlagið í Costco", 22 May.

Morgunblaðið (2017g). "Jón Gerald fagnar komu Costco”, 25 May.

Morgunblaðið (2017h). "Sólveig bjó til „lítið skrímsli“", 29 May.

Nations, S. (2017). A bistory of the United States in five crashes. New York: Harper Collins Publishers.

NRF (2016). "2016 Top 250 Global Powers of Retailing”. Viewed 15 September 2017 at https://nrf. com/news/2016-top-250-global-powers-of-retailing

Oddson, G.Æ. (2010). “Stéttarvitund Íslendinga í kjölfar efnahagshruns”, Íslenska pjódfélagið 1(1), 5-26.

Ólafsdóttir, K. (2017). "Stofnandi íslenska Costco-hópsins á Facebook hefur aldrei komið í Costco" Vísir, 30 May.

Ólafsson, J. (2014). "Viðbrögð við áfalli i lýðræðisríki: Mat lagt á reynslu Íslendinga”, in J. Ólafsson (ed.), Lýdrađistilraunir. Ísland i bruni og endurreisn (pp.7-21). Reykjavík: Háskólaútgáfan.

Ólafsson, S. (2003). “The identity of Icelanders: Scandinavian or American?”, Scandinavian Review 91(1).

Ólafsson, S. (2011). "Iceland's Financial Crisis and Level of Living Consequences. Working Paper no. 3". Djóðmálastofnun - Social Research Centre, University of Iceland. Viewed 10 November, 2017 at http://thjodmalastofnun.hi.is/sites/thjodmalastofnun.hi.is/files/skrar/icelands_financial_crisis_ and_level_of_living.pdf

Pálsson, S.Á. (2017). “Íslendingar ofuráhugasamir um verðlagninguna í Costco” Vísir, 26 May. 
Ragnarsdóttir, S.L. (2017a). “,Allt útpælt“ hjá Costco” Morgunbladid, 26 March 2017. Viewed 22 May 2017 at http://www.mbl.is/frettir/innlent/2017/05/26/allt_utpaelt_hja_costco/

Ragnarsdóttir, S.L. (2017b). "Íbúar í Costco-hverfi komast ekki heim” Morgunbladid, 26 May.

Ragnarsdóttir, S.L. (2017c). "Hillurnar í Costco að tæmast" Morgunbladið, 11 June.

Rannsóknarnefnd Alpingis (2014). "Skýrsla rannsóknarnefndar Alpingis um rannsókn á aðdraganda og orsökum erfiðleika og falls sparisjóðanna”.

RÚV (2014). "Fjármálaráðherra fagnar áformum Costco", 5 July.

Samkeppniseftirlitið (2015, mars). "Leiðbeining um samkeppni á dagvörumarkaði. Staða samkeppninnar 2015". Viewed 7 September 2017 at https://www.google.is/url?sa=t\&rct=j\&q=\&esrc $=\mathrm{s} \&$ source $=$ web\&cd $=1 \&$ ved $=0$ ahUKEwjf2oaF3rjWAhVFQZoKHXGrDxgQFggnMAA\&ur $\mathrm{l}=\mathrm{http} \% 3 \mathrm{~A} \% 2 \mathrm{~F} \% 2 \mathrm{Fwww}$. samkeppni.is $\% 2 \mathrm{Fmedia} \% 2 \mathrm{Fskyrslur}-2015 \% 2 \mathrm{FMatvoruskyrsla2015.}$ pdf\&usg=AFQjCNH0FupVxuvKPFFpF-aY09mzfZTw1Q

Shaxson, N. (2012). Treasure islands: Tax havens and the men who stole the world. London: Vintage.

Sigurðardóttir, K. (2017). “Costco gæti stuðlað að meiri verðlækkun matar” RÚV, 13 June.

Sigurpórsdóttir, S.K. (2017). "Engin ástæða til að bregðast sérstaklega við opnun Costco" Visir, 22 May. Soni, P. (2016). "How Warehouse Clubs Have Transformed the Retail Sector" Market Realist, 19 January. Viewed 15 September 2017 at http://marketrealist.com/2016/01/growth-warehouse-clubs-riseindustry-concentration/

Statistics Iceland (n.d.-a). "Population - key figures 1703-2017 database". Viewed 10 November 2017 at http://px.hagstofa.is/pxen/pxweb/en/Ibuar/Ibuar_mannfjoldi_1_yfirlit_yfirlit_mannfjolda/ MAN00000.px/table/tableViewLayout1/?rxid=01a1037a-34b7-461f-8eb1-d9a5e40637f1.

Statistics Iceland (n.d.-b). "Mannfjöldi eftir kyni og aldri 1841-2017”. Viewed 6 September 2017 at http://px.hagstofa.is/pxis/pxweb/is/Ibuar/Ibuar_mannfjoldi_1_yfirlit_Yfirlit_mannfjolda/ MAN00101.px/?rxid=9dbe2bc7-d035-43d8-9481-6d6c7a84a031.

Strauss, A., and Corbin, J. (1998). Basics of Qualitative Research. London: Sage Publications.

Sæmundsdóttir, S. (2015). "Costco á Íslandi er ekki Costco” Morgunbladið, 10 March.

Thomson Reuters Datastream database and author's calculations (n.d.).

Tsing, A.L. (2005). Friction: An ethnography of global connection. New Jersey: Princeton University Press.

Valgerðardóttir, S. (2017). "Bætiefni blandað í eldsneyti frá Costco" RÚV, 22 June.

Viðskiptablaðið (2017). Bónus lækkar verð í keppni við Costco. Viðskiptabladið, 6 November.

Vilhjálmsson, I.F. (2015). “Álverið í Straumsvík borgar milljarða til móðurfélagsins” Stundin, 3 December.

Vísir (2017). "Mæta samkeppni frá netinu og komu Costco með allt að 40 prósent verðlækkunum”, 11 April.

Walmart (2017). “Only Walmart. 2016 Annual Report”. Viewed 3 September 2017 at https:/ /www.goog-

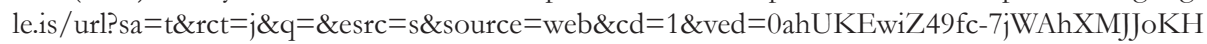
fRnBpYQFggqMAA\&url=https $\% 3 \mathrm{~A} \% 2 \mathrm{~F} \% 2 \mathrm{Fs} 2 . \mathrm{q} 4 \mathrm{cdn} . \mathrm{com} \% 2 \mathrm{~F} 056532643 \% 2 \mathrm{Ffiles} \% 2 \mathrm{Fdoc}$ fin ancials $\% 2$ F2016\%2Fannual\%2F2016-Annual-Report-PDF.pdf\&usg=AFQjCNGzkA-gcS2qn5dC7Qb9TS62VF1e2w

West, H.G., and Sanders, T. (2003). “Introduction”, in H.G. West and T. Sanders (eds.), Transparency and conspiracy: ethnographies of suspicion in the new world order (pp. 1-37). Durham: Duke University Press.

Wilken, R., and Sinclair, J. (2011). "Global Marketing Communications and Strategic Regionalism", Globalizations 8(1), 1-15.

Wood, L.A., and Kroger, R.O. (2000). Doing Discourse Analysis: methods for Studying Action in Talk and Text. London: Sage Publications.

Dorsteinsdóttir, S.Ó. (2017). "Íslenska verslunarmafían svefnlaus af áhyggjum vegna Costco", Kvennabladid, 26 May. Viewed 28 May 2017 at http://kvennabladid.is/2017/05/26/islenska-verslunarmafian-svefnlaus-af-ahyggjum-vegna-costco/

Ægisson, H. (2014). “Costco hefur áhuga á verslun á Íslandi” Morgunbladid, 3 July. 